\title{
ARTYKUtY
}

Klio. Czasopismo poświęcone dziejom Polski i powszechnym PL ISSN 1643-8191, t. 53 (2)/2020, s. 151-161

(c) $(1) \Theta$

JAN ŠTĚPÁN*

\section{Některé př́pady čarodějnictví na Pobečví do období rekatolizace}

\section{Wybrane przypadki procesów o czary na Pobečví aż do czasu rekatolicyzacji}

\author{
Case studies of witchcraft trials \\ in Pobečví region till the recatholization
}

Streszczenie: Uwzględnione w artykule przypadki czarów i magii szkodliwej dotyczą okolic Bečvy i doszło do nich w środowisku protestanckim w latach 1531-1636. Są to przykłady stosowania magii w Przerowie (Přerově), który należał wówczas do panów z Pernštejna, z miasta Lipnika nad Bečvou w czasach protestanckiego księcia Jerzego Starszego Bruntálskiego z Vrbna oraz z miasta Hranice na Morawach z okresu władctwa

Zemský archiv v Opavě - pobočka Olomouc, U Husova sboru 10, 77900 Olomouc, j.stepan@ol.archives.cz, ORCID: 0000-0001-8152-4305. 
Jana z Kunovic. Wszystkie przytoczone praktyki magiczne odpowiadają ówczesnemu postrzeganiu czarów, jako powodującemu szkody ludziom, zwierzętom i mieniu, w celu osiągnięcia korzyści osobistych lub zemsty. Stosowane zaklęcia powinny albo chronić inwentarz żywy przed wilkami, albo przywoływać nieurodzaj lub złą pogodę, powodować śmierć wielu ludzi, dostarczanie szczęścia komuś lub zwiększanie wydajności mlecznej krów, a w jednym przypadku używanie szat zdjętych z powieszonego na szubienicy skazańca miało przyciągnąć ludzi do gospody. Ponadto wspomniane są dwa przypadki zarzutów o czary, demonstrujące zarówno obrazy rzekomej magii, jak i niebezpieczeństwo oskarżenia o takie zachowanie. Cenne jest to, że właściwie wszystkie przypadki dotyczą czasu, kiedy strony podlegały protestanckiej administracji, do którego to okresu na ogół zachowała się niewielka liczba źródeł. W trakcie rekatolicyzacji na ziemiach czeskich zniszczono ogromną ilość materiału, w tym dotyczącego magii i procesów czarownic również w czasach rządów protestantów. Ale przedstawiane sprawy nie różniły się niczym od tych wyłaniających się w środowisku katolickim.

\begin{abstract}
A paper presents several case studies on witchcraft and magic from vicinity of Bečva from 1531-1636. These examples are connected with protestant communities from Přerov owned by masters from Pernštejn, a town of Lipnik on the river Bečva (owned by the protestant prince Jerzy Starszy Bruntálski - Jerzy Older of Bruntal), and a town of Hranice na Moravě (ruled by Jan from Kunovice). All presented practices are an immanent part of a tradition considering magic as tool to cause damages and injuries to people, animals, or properties in attempt to gain personal advantages or to take revenge. As a result, all spells were considered as protecting livestock against wolfs, or causing scarcity, bad weather, death of a number of people, misfortune, or improve quantity of a milk yield, etc. Moreover, two among discussed case studies demonstrate accusations of witchcraft and examples of alleged magic. It is worth stressing, that analysed historical sources are very rare, as most of protestant sources from the period had been destroyed during the process of recatholization. It needs to be noticed, however, that presented cases are identical with cases known from catholic communities.
\end{abstract}

Słowa kluczowe: proces o czary, czarownica, magia, protestanci, rekatolicyzacja

Keywords: witchcraft trials, witch, witchcraft, magic, protestant communities, recatholization

$\mathrm{V}$ íra v čarodějnice a jejich škodlivé nadpřirozené umění, je naneštěstí stará takřka jako lidstvo samo. Mnoho škodlivých jevů, nemocí a neštastných událostí, ke kterým v koloběhu života dochází, totiž hledalo 
v potencionálně „dobrém světě” svou prríčinu. Zlo, které mělo být obsaženo v kouzlech, se v různých kulturách vysvětlovalo od spirituálních hybatelů, $\mathrm{k}$ těm personifikovaným $\mathrm{v}$ osobách čarodějnic a podstatně méně k černokněžníkům. Nebylo totiž snadné vysvětlit, jak je možné, že se dobrý člověk má špatně, či to, že zlý člověk je na tom za života lépe. Taková skutečnost byla proto vysvětlitelná jen zásahem zla, nebo rouháním, nebot́ svět byl Bohem stvořen jako dobrý. Oficiální kouzlení či čarování tak mohl provádět pouze „bělokněžník”, tedy kněz formou modlitby, př́ímluvy ke svatému či mše svaté. Jakákoliv jiná forma bylo čarodějnictví a přisouzeno bylo černokněžníkům a čarodějnicím. Názory na rozdíl mezi kouzelnictvím (Zauberei) a čarodějnictvím (Hexerei) se v současné literatuře liší spíše podle toho, zda jde o součást téhož spolku s dáblem, či zda je kouzelnictví samostatným jevem ${ }^{1}$. Nutno konstatovat, že raném novověku tento pohled nebyl i přes dobovou sofistikovanou literaturu tak složitý, nebot samotné obvinění vždy počítalo s čarodějnictvím a jiný úradek než dáblův se zde nepředpokládal. V př́ípadě prokázání viny tak kouzelnicím i čarodějnicím připadl jediný trest - upálení.

Co se týče nejstarších dokladů kouzelnických či čarodějnických praktik v českých zemích v novověku, uvádí Petr Kreuz nejstarší doklad takových praktik pro Kutnou Horu a Prahu v roce 1498, kdy zde některé ženy kohosi „trávily a mořily nějakými prachy” 2 . Autor také poukazuje na rozdíl mezi zmíněným kouzelnictvím a čarodějnictvím a případy podle toho člení. Naopak Kamila Rojč́ková, které se pokusila souhrnně zpracovat př́ípady čarodějnictví na Moravě do roku 1648 mezi kouzelnictvím a čarodějnictvím nerozlišuje a vše zahrnuje pod čarodějnictvî̉ ${ }^{3}$ Většina jí uvedených př́padů je ovšem podle předchozí definice kouzelnictvím, autorka však posunula hranici k letům 1487 a 1494 do Uherského Hradiště, kde byly projednávány př́pady škodlivých kouzel a nařčení z magických ublížení

${ }^{1}$ P. Kreuz, Kouzelnictví a jeho pronásledování v jagellonské Praze, „Pražský sborník historický” 2012, Roč. XL, s. 131-132; Z. Kobrlová, Sdružený zločin čarodějnictví a České zemé, „Paginae historiae” 2015, Roč. 23, č. 1, s. 104-106.

2 P. Kreuz, op. cit., s. 135.

3 K. Rojčíková, Čarodějnické procesy na Moravě do roku 1648, „Časopis Matice moravské" 2001, Roč. CXX, s. 187-207. 
na těle ${ }^{4}$. Mimo to uvádí další případy z Jihlavy $(1554,1559,1591)$, Velké Bíteše (1571-1576), Ženklavy (1592), Znojma (1633) a Vŕesovic (1637), kde se uvádí spojení s d’áblem či zlými duchy, tedy jednoznačné čarodějnictví (Hexerei).

Z hlediska vlastní bezpečnosti v raném novověku, bylo vždy dobré přisoudit neštěstí někomu jinému, než se rouhat a fakticky se tak stát špatným. Neštastnou byla také jedna věta v bibli, která ř́ká „čarodějnici nenecháš živou býti” a prostor pro to, čemu dnes říkáme „hony na čarodějnice” byl v zásadě připraven. Není zde důvod rozebírat, který př́ípad byl první, zda v některém století docházelo k méně případům, ani která část Evropy, či naší země, byla této víře více nakloněna. Každopádně zlomek dodnes dochovaných případů ukazuje, jak v určitých oblastech docházelo $\mathrm{k}$ hledání př́čin zla personifikovaných do údajných kouzelnic/čarodějnic a $\mathrm{v}$ jiných ne. Je jen jasné, že podle všeho alespoň v určitých oblastech vítězil rozum a hranice, které měly být tím jediným, co čarodějnici spolehlivě zničí, plály jen někde.

Jeden př́klad za všechny. $S$ popravišti a těly popravených souvisela řada pověr a kouzelných praktik, které přitahovaly řadu lidí a slibovaly získání štěstí, zdraví, financí, nezranitelnost apod'5 Samožrejmě šlo o zakázané praktiky a tak se o většině těchto magických praktik dozvídáme zpravidla opět $\mathrm{z}$ výslechů lidí obviněných $\mathrm{z}$ nějakého zločinu či přímo $\mathrm{z}$ popisu čarování. Ve většině prrípadů se jednalo o užití částí těl a oblečení popravených, oprátky, ze kterých prý dokázaly čarodějnice dojit mléko apod. Čarovnou moc měla mít také hlína z popraviště a hlavně rostlina mandragora, která se používala $\mathrm{k}$ magickým praktikám. Mandragora prý rostla pouze na popravištích a získat ji bylo možné jen tak, že se člověk vystavil smrtelnému nebezpečí. Zajímavé je, že se tato víra traduje v podstatě dodnes a dočkala se i zajímavých filmových zpracování jako třeba v Císařově pekaři, kde je scéna zasazena na pražský šibeniční vrh, či zpodobnění jejího pěstění mimo popravišstě v Harry Potterovi díl Tajemná komnata.

4 Ibidem, s. 189-190.

5 D. Wojtucki, Magic at the gallows, dealing with the bodies of executed convicts in Silesia and Upper Lusatia in the early modern period / Limbs, bones and reopened graves in past societies, Bytów 2015, s. 377-404. 
Ovšem již lékař a botanik Petr Ondřej Matthioli ve svém herbáři v české verzi z roku 1562 prokázal, že jde jen o podvod, který však nebránil pověrčivým lidem těmto praktikám nadále věritit. Mathiolli o mandragoře píše: Dryáčníci a šejdírii, kteříž s hrubými krámy po světě jezdí, prodávají jeden kořen, ku podobenství muže aneb ženy zformovaný, a namlouvají lidi, kterak ho tě̌̌ce dostávají, že jej musejí pod šibenicí s velikým strachem a nebezpečenstvím života vykopávati, psa černého za provaz $\mathrm{k}$ tomu kořenu prívázati, sami sobě uši smolou aneb voskem zacpati, aby kvílení a křiku téhož kořene neslyšeli, nebo jakž jej uslyší, že by ihned tu na místě zemřeli a hrdla nechali. Co jest to medle jiného, nežli což o kapradí ŕíkají, že kdož semeno jeho chce míti, musí smělý býti a čerta se zmocniti: takovým bláznovstvím a obludami sluš́ lidi šáliti a mámiti (qui vulgus vult decipi). A k tomu já ted' jsem, volá na rynku dryjáčník, abych to dělal. Protož řemeslně sobě to vymyslili a kořen takový draho prodávají, připisujíce mu divné moci, jakoby lidem, zvláště očarovaným a okouzleným, štěstí dával, neplodné ženy plodné činil, aby toho mužíčka každou sobotu vínem a vodou zmyli, do čisté rouchy obalili a v tajnosti chovali. Ale věděti má dobrotivý čtenár, že takový kořen mandragory aneb mužíček jest pouhá báseň a kleveta, k oškrábání prostých lidí o peníze nastrojená.

Nebo ti šejdiŕri sami jej tak ku podobenství muže aneb ženy formují a vykrajují z koření posedového aneb kosatcového, a to tehdáž, dokudž jest mladistvé a čerstvé. Kdež vlasy míti chtějí, tu vloží zrno ječné aneb prosné, potom zahrabí kořen tak vykrájený do písku a nechají tam až se zrna zejmou a vláseníčko z sebe vydají, což se obyčejně stává ve třech nedělích. Naposledy zase jej vykopajíce obřeží a to vláseníčko přirostlé ostrým nožem ostrouží a tak subtilně jej zformují, aby se zdál míti vlasy a chlupy na hlavě, na bradě i dole a tudy hloupé lidi oklamávají. To šibalstvo oznámil mi sám jeden dryáčník v Římě, když jsem ho na franckou nemoc hojil, ukázal mi některé $\mathrm{z}$ těch řezaných kořenů a pověděl, že časem bohatým lidem jeden za třicet dukátů prodával. Ačpak koli nahoře dotčené ceremonie a pověry, kteréž by měly zachovávány býti při vykopávání toho kořene, vypsal poněkud dávno Flavius Josefus v knize 7 de bello Iudaico v kapitole 25, však tam

6 P. O. Mathioli, Herbár aneb bylinár̆, Praha 1596, Reedice B. Kočí, Praha 1924-1928 , fol. 392v-393r. 
nepíše o kořenu mandragory, ale o jiném kořenu, jménem Baaras, kteříž jest neznámý.

Případy, které zde budou zmíněny, se týkají oblastí v okolí Bečvy (která na to ale nemá vliv, jde jen o přibližné vymezení), kde došlo k několika zajímavým kouzelnickým př́padům, které jsou zároveň pozoruhodné tím, že se udály $\mathrm{v}$ protestantském prostředí. $\mathrm{V}$ rámci rekatolizace totiž bylo v českých zemích zničeno obrovské množství materiálů, včetně těch, prokazujících kouzelnické a čarodějnické procesy také v éře protestantů. Nebyly totiž ničím rozdílné od těch vznikajících v katolickém prostředí. Dále tedy budou představeny př́pady z města Přerova, které $\mathrm{v}$ té době patřilo protestantským pánům z Pernštejna, tř́i př́pady z Lipníka nad Bečvou z doby protestanta Jiř́iho staršího Bruntálského z Vrbna a jeden z Hranic z doby protestanta Jana $z$ Kunovic a na Uherském Brodě. Mimo to na závěr zmíníme ještě dva prŕpady údajného kouzelnictví ze stejného období k dokreslení dobového pohledu.

Zatím nejstarší doložená zpráva o kouzelnicích v Přerově pochází z Nekrologia jednoty bratrské a vztahuje se k roku $1531^{7}$. Podle zprávy zde tehdy kouzelnice mimo řadu dalších lidí otrávily také přerovského jáhna, kantora a lékaře Víta i s rodinou „potom v Přerově rozmohly se čarodějnice, kteréž mnohé lidi připravily o životy”" . Lékař Vít měl být původně také jáhen, měl nižší šlechtický titul, byl ženatý, měl syny a dcery, byl zbožný, těšil se dobrému zdraví a byl při těle. To vše stojí v záznamu na podivení, že kouzelnice zabily takového člověka i s celou jeho rodinou, respektive, že jej nic neochránilo. Nejpravděpodobnější vysvětlení celé události je nějaká nakažlivá nemoc a sám lékař ji nejspíše dostal od nemocných, přičemž následně nakazil celou svou rodinu.

Zdá se, že nějakou dobu poté byl v Přerově klid, ale ze zprávy v roce 1559, kterou vydalo olomoucké vrchní právo Přerovským, vyplývá, že opět došlo k nějakým nevysvětlitelným událostem9 ${ }^{9}$ Přerovští, kteří si nevěděli

7 Nekrologium Jednoty bratrské 1572, Praha: Národní knihovna ČR, sign. XVII E 69, fol. 118r.

8 L. Hosák a kol., Déjiny města Přrovova I., Přerov 1970, s. 174.

9 V. Prasek, Organisace práv magdeburských, Olomouc 1900, s. 141, zde však není zmíněn list z folia $96 \mathrm{v}$. 
s př́padem rady, zaslali do Olomouce rozsáhlý spis, ve kterém jim popsali události, k nimž mělo dojít asi před dvaceti lety, kdy měla jakási Klimentka Kovářka obvinit z čarodějnictví také své dvě dcery Annu a Martu ${ }^{10}$. Tyto dcery byly pravděpodobně zproštěny vinny, přinejmenším Marta, protože ji v roce 1559 nejspíše opět nařkli z čarodějnictví. Obvinění zřejmě bylo vážné, protože se dozvídáme, že na jeho základě mohla být Marta předána útrpnému právu a mučena. Je také možné, že šlo o pokračování případů z roku 1531.

Další zprávy k jejímu osudu sice nemáme, ale zdá se, že údajné čáry neustaly. Mezi červnem a červencem 1561 totiž Přerovští opět žádali radu ve věci kouzelnic. U jakési pivovarnice Jankové našli jako doličné předměty různé koření, vosky, suchou žábu a další předměty, které je utvrdily v tom, že se jedná o čarodějnici. Mimo Jankovou měla být dále útrpným právem vyslýchána Urbanková a na základě výslechu mělo být postupováno proti dalším osobám. Zdá se, že shledané výpovědi jen potvrdily kouzla a čáry, protože podle následující odpovědi byly obě tyto údajné kouzelnice hned druhý den popraveny, a to pro „dábelské skutky”.

Opět se v radě Olomouckých uvádí, že se mají podobně zachovat také k ostatním, o kterých se ve výslechu píše a výjimky činily pouze Kuna Wandělková a sestra popravené Jankové Dorota, které byly obě těhotné a s dalšími výslechy a př́padnou popravou se mělo počkat až po porodu. Poté šly události poněkud pomaleji, ale přesto byly na základě těchto výslechů upáleny další čarodějnice. Dále byly totiž vyslýchány Bahnová, Hlavková, Waincová a Vojtková, ale zdá se, že jejich přičiněním byly nakonec obě těhotné ženy Kuna Wandělková i sestra Jankové Dorota a navíc Kateřina Waincová, omilostněny. Když byly totiž čtyři vyslýchané ženy na hranici před upálením, odvolaly svoje výpovědi a zdá se, že tak bylo rozhodnuto ve prospěch zmíněných tří žen, které tedy neměly s čarami mít nic společného. Propuštěny z vězení však přesto mohly být až poté, co se za ně zaručili hodnověrní rukojmí.

10 Státní okresní archiv Olomouc, fond Archiv města Olomouc signatura M 1-1, Naučení a rozsudky vydaná městskou radou (Liber sentenciarum) z let 1558-1567, kniha č. 197, inv. č. 2043. 
Z Lipníka nad Bečvou máme prozatím dva prímé a jeden nepřímý doklad kouzelnických praktik. V roce 1600 byl v Lipníku vyslýchán pastýr Jakub z Lazník, který byl obviněn kromě řady krádeží také z čarování. Mimo jiné prý od roku 1598 měl ve sklenici čerta, kterého koupil od svého stejnojmenného předchůdce, kterým škodil cizím stádům, na která čerta posílal ve vlčí podobě. Když jej odmítli přijmout v Chýlci (dnes Veselíčko) za pastýře, poslal na ně čerta, který způsobil strašné krupobití. Dále si prý schovával při mši Tělo Kristovo, ale i přes mučení neprozradil, co s ním dělal a o čertu prohlásil, že jej u Chýlce vhodil do propasti u nějaké křižovatky. Pastýr Jakub byl nakonec upálen ${ }^{11}$. V roce 1619 bylo vyslýcháno několik žen, obviněných z čarování, kdy nejprve v březnu prozradila Kateřina Crbonka nejspíše z Lazník, že zabila několik lidí podle receptu jakési Boudkové. Ta jí poradila, aby na ohni spálila „chrástavé” žáby (ropuchy) a koho pak posypala popelem, musel uschnout tak, jako oheň vysušil žáby. Mimo to dala svému bratru do vězení bylinu „laskavec”, aby jej brzy propustili ${ }^{12}$. Poslední čarování, kterého se měla dopustit, bylo „uzamčeni”” dobytka na pastvě. Stádo prý obešla s motlitbou „Toho mi dopomáhej Bůh Otec, Syn i Duch svatý, na věky požehnaný, amen” a ke stádu pak nemohli vlci. Při tom je také pokropila vodou $\mathrm{z}$ uvařeného vlč́ho masa.

Navazující je výslech Anny Boudky v květnu roku 1619 pro čarování, kdy byla obviněna také z toho, že předpovídala počasí. Stejně tak uvedla, že s Crbonkou pálily žáby a zabily tak několik lidí, svého muže ale zabila tím, že spálila své vlasy a dala mu je vypít. Jakéhosi sedláře očarovala tak, že měl nohy jako v ohni za to, že ji prý udeřil hůlkou, ale když ji odprosil, vyléčila ho bylinou „slunočník” ${ }^{13}$. Popelem z žab dále trávily panský a jiný dobytek, když se chtěly mstít. Kravám odebíraly mléko tím způsobem, že chodily na křižovatky mezi Lazníky a Velký Újezd, kde braly hlínu, tu smíchaly s posečeným „smetaníkem” a dalšími bylinkami a vložily do lýčeného provazu, ze kterého pak dojily mléko ${ }^{14}$. Sestra Crbonky Zuzana prý ještě z domu, které-

11 M. Marada, Smolná kniha města Lipníka, Přerov 1994, s. 29-30.

12 Nejspíše se jedná o třezalku tečkovanou, jedno z jejích lidových pojmenování je laskavec.

13 Snad jde o bylinu otočník (Heliotropium maius), které se také říká slunečná bylina.

14 Smetaník je pravděpodobně pampeliška = smetanka lékařská. 
mu chtěla škodit, odřezala tř́sky ze dveř́í, které pak dala žrát svým kravám a ty dojily více na úkor krav z poškozeného domu. Aby jim slepice nosily dvě vejce za den, zařizovaly tak, že na Štědrý den a Boží narození braly hlínu z devíti krtičinců a přidaly do ní zrní, které dávaly slepicím. Mimo jiné ještě řekla, že vředy na nohách úředníka na Veselíčku mohlo způsobit kouzlo, kdy se „všelijakých kostí úmrlčích jak člověčích, koňských, psích i kočičích” vyvaří a nalejí na cestu, po které dotyčný přejde ${ }^{15}$. Prý by mu dokázala pomoci, kdyby se na nové pondělí, čtvrtek a sobotu (tedy o Velikonocích) nabralo černých mravenců z devíti mraveništ a svařili se s bylinami „Mahela slove uherská zelina, královská zelina a trápenî”' ${ }^{16}$. Více o př́padu nevíme.

$\mathrm{V}$ roce 1636 byl popraven kolem ovčák Bartoň ze Slavkova a „na čtvrtý den kdosi klíny odspodu zdobýval, až se kolo pošinulo tak, že je mohl rukou dosáhnouti mohl, dvě oprátky odřezané byly, potom poručeno mistru by to do spravedlnosti hodil a nikdo aby víc nehřešil" ${ }^{17}$. Je zřejmé, že víra $\mathrm{v}$ kouzelné praktiky přetrvávala $\mathrm{i} v$ rekatolizovaném městě krátce po ukončení působní jezuitů. Z Lipníka máme ještě jeden př́ípad, který ale naneštěstí není datován a obsahuje jen velmi málo informací, je tedy spíše uvedeným př́padem dokreslujícím dobovou situaci. V knize právních naučení města Olomouc městu Lipníku totiž nacházíme hned jako druhé naučení „o čáry učiněné nářek” ${ }^{18}$. Podle naučení totiž dvě ženy obžalovaly třetí z toho, že je „o jejich zdraví připravila svými čáry”, proti čemuž obžalovaná podala odpor, že nic takového neučinila. Víme jen, že Olomoučtí rozhodli, že údajná čarodějnice svůj odpor nepodala dostatečně přesvědčivě a má být proto dále vyslechnuta. Není ale nijak známo jak prrípad dopadl a nemluvilo se zde o žádném výslechu formou mučení. Zmiňme ještě krátce prrípad z nedalekých Hranic, kde po popravě dvou lotrů v roce 1574, kteří byli vztyčeni na kole, dvě dívky jednomu z lotrů uřezaly „kus košile,

15 M. Marada, op. cit., s. 47.

16 Královská bylina - snad řepík lékařský Köngskraut.

17 Moravský zemský archiv v Brně, sbírka rukopisů G 10, sign. 283, fol. 132r.

18 Státní okresní archiv Přerov, fond Archiv města Lipník nad Bečvou, kniha č. 40, fol. 3 r. 
chtíc čarovati, aby mnoho hostí na pivě měly" ${ }^{19}$. Navedla je k tomu majitelka hostince Písková, všechny tři byly mučeny katem a vypovězeny z města.

Poslední případ pochází z obce Věrovan na Tovačovsku, který opět ukazuje, jak jednoduše bylo možné někoho obvinit z čarodějnictví, i jaké představy o kouzlech/čarách $\mathrm{v}$ dané době byly. $\mathrm{V}$ roce 1584 zde totiž bednář Matouš Slavík z Tovačova nařkl Annu manželku Václava Pohůnka z Věrovan, „že by ji tu sobotu před Velikonocí na poli ve svítání když do Olomouce šel viděl že po poli kočkau lezla a rosu k čárům do hrnce zbírati měla a k tomu také že by na svatého Filipa Jakuba nahá v gruntě svém s dobytým mečem běhati a do dveří chlívových tím mečem bosti měla" ${ }^{20}$. Tato rozepře byla ukončena formou odprosu a zdá se, že Anna nebyla prohlášena čarodějnictví. Ostatně v tomto př́ípadě jde o očividný akt sousedské msty, ale je zajímavý alespoň tím, že nám ukazuje podobu představ o tehdejších čarodějnicích a jejich kouzelných rituálech.

Uvedené doklady ukazují pohled na vnímání kouzel a čarování v období necelých sto let $\mathrm{v}$ jednom regionu. $\mathrm{V}$ této době $\mathrm{v}$ podstatě všechna kouzla odpovídají dobovému vnímání čarodějnictví jakožto způsobení škody lidem, zvíratům a majetku za účelem získání osobního prospěchu či pomsty, z dnešního pohledu bádání tedy spíše kouzelnictví. V žádném z uvedených případů nebylo prokázáno, ale podle dokladů ani hledáno mladší spojení s dáblem (pakt, sabat či jakýkoliv styk s démony). Nelze tak vnímat ani výběr vhodných dní v roce pro kouzlení či sběr magických ingrediencí, nebot odpovídá starobylým pohanským praktikám zemědělského roku, nikoliv mladšímu spojení s čarodějnickými procesy, které v uvedené dny spojení s dáblem teprve přinesly. Magické praktiky proto nejsou nijak složité, lze říci, že zde jde jen o užití již zmiňovaných škodlivých kouzel (Schadenzauber). Cenné je, že se prakticky všechny př́ípady týkají období, kdy lokality spadaly pod protestantskou duchovní správu, ke kterému se dochovalo malé množství pramenů.

19 B. Indra, A. Turek, Paměti drahotušských kronikárúu 1571-1911, „Časopis Vlasteneckého spolku musejního" 1946, č. 55, Olomouc 1947, s. 21.

20 Zemský archiv v Opavě pobočka Olomouc, fond Velkostatek Tovačov, inv. č. 1207, gruntovní kniha Věrovan, fol. 30r, v. 
Uvedené případy kouzelnictví, se týkají oblastí v okolí Bečvy a odehrály se v protestantském prostředí z let 1531-1636. Jde o doklady o užívání kouzel v Přerově, které v té době patřilo protestantským pánům z Pernštejna, v Lipníku nad Bečvou z doby protestanta Jiř́ho staršího Bruntálského z Vrbna a v Hranicích na Moravě z doby protestanta Jana z Kunovic. Všechna zjištěná kouzla odpovídají dobovému vnímání čarodějnictví jakožto způsobení škody lidem, zviŕatům a majetku za účelem získání osobního prospěchu či pomsty, z dnešního pohledu bádání tedy kouzelnictví. V žádném z uvedených př́padů nebylo prokázáno, ale podle dokladů ani hledáno mladší spojení s dáblem (pakt, sabat či jakýkoliv styk s démony). Uvedená kouzla měla bud' chránit stáda před vlky nebo přivolat neúrodu či špatné počasí, způsobit smrt několika lidem tzv. uschnutím, přinést někomu štěstí nebo zvýšit dojivost krav a v jednom prŕípadě za použití oblečení oběšence prrilákat lidi do hostince. Mimo to jsou zmíněny dva př́ípady nařčení z čarodějnictví, které jednak demonstrují představy o údajném čarování a zároveň nebezpečí z nařčení takového jednání. 
